\title{
Changed knowledge requirements for spatial flood governance
}

\author{
Emmy Bergsma $^{1}$
}

ABSTRACT. Floods have not only occurred with greater frequency, they have become more damaging over the years. The associated rising costs have challenged traditional governance approaches that aim to provide full protection against floods. By aiming for protection, these approaches have allowed value to accumulate in high-risk areas. Now that climate change puts more floods on the horizon, policy-makers around the world have turned to "spatial-planning" measures that aim to reduce exposure to flood risks rather than provide full protection. This policy transition not only involves the development of new policy approaches and governance arrangements, it places new requirements on knowledge to support these approaches and arrangements. I analyze these changed knowledge requirements in a case study on the Netherlands. The Netherlands thrived on a technical safety approach in the 20th century, but since the late 1990s, a number of spatial planning policies have been forwarded. Building on the policy arrangements framework as a conceptual model, I add a new knowledge dimension to this framework to analyze what new knowledge requirements emerged in the Dutch turn to spatial-planning measures and how these new forms of knowledge could be organized within existing safety institutions. Based on the analysis, I conclude that spatial-planning measures require new forms of "localized" policy knowledge to support the more decentralized responsibility structures that underpin spatial-planning measures. I also conclude that this form of expertise may be difficult to organize within safety institutions due to the strong interactions between nationally oriented engineers and policy-makers that characterize safety approaches.

Key Words: experts; flood governance; knowledge; policy arrangements framework; spatial-planning

\section{INTRODUCTION}

Over the last two decades, traditional "safety" measures have lost their forthright appropriateness as a flood governance strategy. Safety measures such as levees and floodwalls have reduced the chance of flooding, but they have not necessarily reduced the risk (understood as the probability and potential consequences of a flood event). Contrarily, they have allowed value to accumulate in flood-prone areas, thereby increasing the potential for disastrous flooding disasters, as was vividly demonstrated by hurricane Katrina in 2005 (Hartmann 2009). Increasingly, policymakers are shifting their attention to "spatial-planning" measures in flood governance (Klijn et al. 2008, Bubeck et al. 2012).

Spatial-planning or land use measures aim to minimize the impacts of a flood (Hall et al. 2003, Pottier et al. 2005). They typically consist of a range of regulatory and pricing policies that fall within the scope of two "flood risk management strategies" outlined by Hegger et al. (2014): flood prevention and flood mitigation. In terms of flood prevention, spatial-planning measures, for example, include the widening and deepening of rivers, and restrictions on building activities in high-risk areas to create more space for water. In terms of flood mitigation, examples of spatial-planning measures are the designation of emergency water retention areas, and the use of regulatory or pricing instruments that incentivize the development of floodproof building structures (e.g., by elevating buildings, using waterresistant building materials, and applying flood-proof construction modes) to mitigate flood damage.

Incorporating spatial-planning measures under a traditional safety approach has major implications for existing arrangements in flood governance (Wiering and Immink 2006, Ward et. al 2013, Hegger et al. 2014). Scholars have already drawn attention to the discursive shifts underlying this policy change (Wiering and Arts 2006), have pointed out that spatial planning often requires a more decentralized governance structure (Johnson and Priest 2008,
Meijerink and Dicke 2008), and have highlighted changed allocations of costs and benefits under a spatial approach (Penning-Rowsell and Pardoe 2012, Paudel et al. 2015). Analysts often also underscore that the turn to spatial-planning measures requires new forms and organizations of knowledge (McDonnell 2008, Birkmann and von Teichman 2010, van Herk et al. 2011, Vink et al. 2013). However, what new knowledge requirements actually emerge in this process, and whether and how these forms of knowledge can be organized within existing safety arrangements has not been analyzed in much detail yet. Consequently, possible obstacles connected to the role of knowledge in the development of a spatial-planning approach in flood governance may not be sufficiently understood.

The literature on the role of knowledge in public policy-making generally emphasizes that the boundaries between science and politics are blurred and open to contestation. Because of this, knowledge is coproduced at the margins of these boundaries rather than in the restricted setting of the scientific domain, which creates opportunities for (strategic) alliances between policy actors and scientists in the knowledge production process (Jasanoff 2004). While the interrelationships between science and policy in the knowledge production process itself have been analyzed quite extensively (e.g., in "boundary" or "bridging" organizations [cf. Hahn et al. 2006, Rathwell and Peterson 2012]), less is understood about how this relationship is influenced by, and shapes, other institutional factors in the policy-making process (Cash et al. 2003, Crona and Parker 2012).

I aim to contribute to a better understanding of the role of knowledge in the turn from a safety to a spatial-planning approach in flood governance. The analysis focuses on a case study in the Netherlands, where spatial-planning measures have recently been forwarded to broaden the strong safety paradigm that traditionally characterizes Dutch flood governance. Using the policy arrangements framework as an analytical tool, I 
identify which new knowledge requirements emerged in the turn to spatial-planning measures in Dutch flood governance, and whether and how these knowledge requirements could be organized within (the science-policy interactions that characterize) the existing safety arrangements. The conclusions help generate building blocks for an international evaluation of knowledge requirements underlying the turn to a spatially oriented flood governance strategy.

The paper is organized as follows. Section 2 explains the theory and research methods. The Dutch case study is described in Section 3. Section 4 presents the findings and discusses their relevance from an international perspective.

\section{RESEARCH DESIGN}

A knowledge dimension in the policy arrangements framework In this paper, the shift from a safety to a more spatially oriented flood governance strategy is understood as a process of institutional change. Institutions are patterns that structure social interaction (March and Olson 1989), and in a policy field, refer to the standard way in which policy problems are perceived and acted upon (Hajer 2005). In principle, institutions are characterized by a strong path dependency; as Giddens (1984) famously argued, because institutions are reproduced every time they are acted upon, they provide stable structures that tend to endure over time. However, this internal stability is constantly challenged by external and agency drivers (Kingdon 1995). External drivers such as shock events (e.g., a flood) or changing political ideologies can undermine the logic of appropriateness underlying existing institutions. They may open a "window of opportunity" for change, which can be used strategically by actors with an interest in changing the institutionalized environment. At the same time, these drivers of change are counteracted by the internal stability produced by institutions, often actively upheld by vested actors with an interest in preserving the status quo (Arts and van Tatenhove 2004). Institutional change usually encompasses a complex process in which internal, external, and agency drivers closely interact.

The policy arrangements framework (PAF) offers guidance to an analysis of processes underlying institutional change. A policy arrangement can be defined as a "temporary stabilization of the content and organization of a policy domain" (Van Tatenhove et al. 2000:54); it thus describes the internal institutional structure of a policy field. The PAF distinguishes between four dimensions of this internal structure. The discourse dimension provides substance to a policy domain; it refers to the interpretive frame through which policy situations are understood and acted upon (Hajer 2005:300). The discourse dimension links into three "organizational" dimensions: the actor, the resources, and the rules dimension (Arts et al. 2000:57-65). The actor dimension denotes the actor groups (and their coalitions) that are typically involved (or not involved) in policy-making practices; it encompasses "political agency" in the policy domain. The rules dimension refers to the "rules of the game" that structure the (inter)actions between different actors in the policy domain. These rules can be formal (i.e., legally anchored) and informal (i.e., routinized practices). The resources dimension refers to the allocation of resources (e.g., decision-making power, financial resources, and knowledge) over different actors. This dimension encapsulates power in the Laswellian sense of "who gets what, when, and how."
When these dimensions in a policy field are stable - when an established policy discourse is upheld by stable actor groups, standardized rules and practices, and an accepted division of resources - they form a policy arrangement. However, as Arts et al. (2006:100) stress, stability in a policy field is only temporary because existing policy arrangements are continuously challenged by external and agency drivers. Change can originate at each dimension of the policy arrangement, but change brought about at one dimension can prompt shifts at other dimensions, thereby leading to institutional change. In this process, the internal structure of the policy arrangement determines the opportunities for, and directions of, change at each dimension (Arts and van Tatenhove 2004:5). While the different dimensions are interrelated and therefore partly overlap in this process, the main contribution of this framework lies in its accentuation of different "focal areas" for analyses of institutional change (Liefferink 2006:45-46). Rather than understanding institutional change as one "encompassing" process, the PAF allows analysis of the processes that underlie institutional change by drawing attention to different aspects of institutions that can change, at the same time stressing their interrelations.

In discussions and applications of the PAF, knowledge is generally underlined as an important factor for understanding institutional dynamics (Arts et al. 2006:102, Hegger et al. 2012). Institutionalized forms of knowledge often provide a justification for existing policy arrangements, but new forms of knowledge can challenge the framework upon which these arrangements rest. In the PAF, knowledge is usually incorporated under the resources dimension, where it is construed as one of the (strategic) means actors can employ to influence public policy-making (Arts et al. 2000:60, Wiering and Immink 2006:425). However, for an analysis of the role of knowledge in institutional change - as I set out to do-it makes sense to highlight knowledge as a separate dimension in the PAF, as is depicted in Fig. 1. In this elaborated framework, knowledge is recognized as a distinct but integral aspect of policy arrangements, subject to institutionalization and change, and inherently related to all the other dimensions of the PAF. Rather than using a prelabeled category to define knowledge (e.g., Maasen and Weingart [2005] restrict their analysis to scientific advice committees), I use a more empirically grounded and constructionist understanding of knowledge as claims to expertise that are recognized by actors involved in the policymaking process (Jasanoff 2004).

By analyzing knowledge in relation to the other dimensions of the framework, science-policy interactions underlying institutional change can be analyzed in more detail. First, the framework can help to grasp how knowledge is constituted as part of the policy arrangement and how it changes in relation to the other dimensions (i.e., discourse, actors, resources, and rules) in the process of institutional change. Second, it enables an evaluation of the effects of institutional change; does the new policy arrangement require new forms or organizations of knowledge, and have these new knowledge requirements been met? In this paper, these two aspects are researched in the specific context of the turn to spatial-planning measures in Dutch flood governance. I analyze (a) how the policy arrangement-including the knowledge component - in Dutch flood governance changed with the turn to spatial-planning measures, (b) what new knowledge requirements emerged to support this new policy 
Fig. 1. Knowledge in the policy arrangements framework, adopted and adapted from Arts et al. (2006:99).

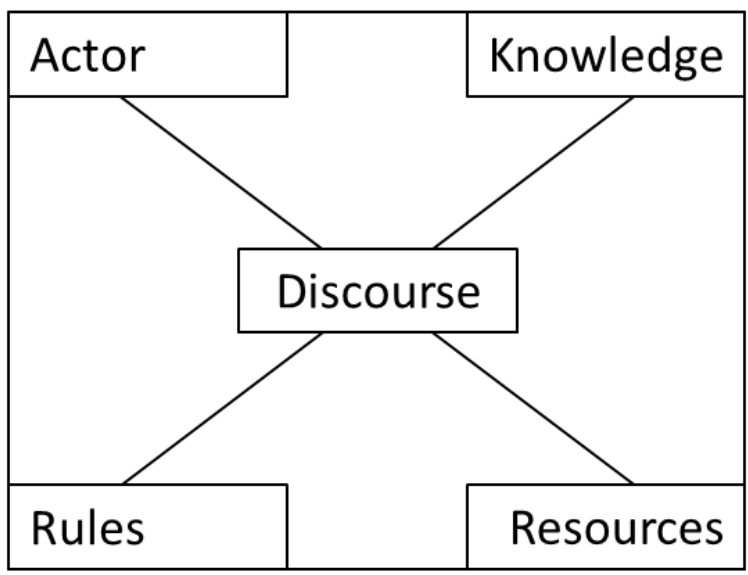

arrangement, and (c) to what extent these knowledge requirements have been met.

\section{A case study on Dutch flood governance}

More than any other country in the world, the Dutch depend on flood safety measures to keep floods (literally) at bay. Dutch flood protection standards are among the highest worldwide. While reinforcing the flood defense system remains a key strategy to deal with flood risks, since the late 1990s, spatial-planning measures have been incorporated into the Dutch policy framework on floods to better deal with the impacts of climate change (Vis et al. 2003). After more than a century of building against floods, this accepting attitude toward floods marks a major break in the existing governance path (Jong and van den Brink 2013). This shift has brought major changes to the organization of Dutch flood governance (Meijerink 2005, Bergsma et al. 2012). The Netherlands thus provides a useful case to examine new knowledge requirements that emerge with the implementation of spatial-planning measures.

From an international perspective, Dutch flood governance represents an "extreme" case. There is no other country where the safety approach has so deeply institutionalized as in the Netherlands. According to Yin (2009:52), extreme case studies may help "reveal insights about normal processes," which would be harder to detect in "common" cases, precisely because they offer a distinct opportunity to study the research subject in a comprehensive and detailed manner. While the degree of change at the knowledge dimension of the policy arrangement in flood governance may be less extreme in other national contexts where the flood safety paradigm has institutionalized less, the insights derived from the Netherlands may provide the basis for an evaluation of changed knowledge requirements underlying the shift to spatial-planning measures management in other countries.

In the case study, the focus is on three key spatial-planning policies forwarded by the Dutch national government. The first is the Room for the River program, which was initiated in the late 1990s to create more space for (flood)water in the Dutch national landscape. This policy grew to be one of the new pillars of Dutch flood management. Second, attempts to launch a private insurance scheme against flood damage are analyzed. Forwarded to place more emphasis on flood damage mitigation at the local level, private flood insurance never effectuated as a new policy measure due to strong resistance against its market-oriented underpinnings. The third is the adoption of the concept of "multilayered safety" in the Second Delta Program, launched in 2008 to invigorate Dutch flood protection, which highlights the importance of flood-proof spatial planning as part of the national flood management strategy.

For each of these policies, the next section reconstructs the policymaking process underlying their (in case of flood insurance: near) implementation. Transcripts of parliamentary debates during which the policy measures were discussed were used as a primary source of data. These data were supplemented with reports and statements from key actors involved in the policy-making processes (e.g., advisory or regulatory organizations). Based on these reconstructions, I examine how the policy arrangement in Dutch flood governance changed during the policy-making process, what new knowledge requirements emerged from these changes, and whether these requirements have been met.

\section{THE IMPLEMENTATION OF SPATIAL-PLANNING POLICIES IN THE NETHERLANDS}

\section{Introduction: the Dutch safety approach}

With more than $50 \%$ of the national surface below sea level and about $70 \%$ of all properties located in these areas (van der Brugge et al. 2005:164-176), a flood potentially has huge consequences in the Netherlands. For this reason, floods have always been considered a collective risk, and protection against this risk a collective responsibility. Flood protection in the Netherlands emerged as a public responsibility, heavily reliant on governmental funding and characterized by a centralized decision-making structure. While important management tasks are delegated to regional water boards, policy goals and objectives for flood protection are specified at the national level by the responsible ministry (the Ministry of Transport, Public Works and Water Management [V\&W]; after its name change in 2010, now referred to as the Ministry of Infrastructure and the Environment[I\&M)]. For example, water boards manage the local water system to support flood safety standards, but these standards are set at the national level. Damage compensation is also largely a national state responsibility; in cases of major floods, the Dutch government usually compensates private losses.

Engineering expertise forms the dominant source of knowledge in this policy domain (Heezik 2007). Policies in this domain are developed in close cooperation with the Rijkswaterstaat-a central water management authority renowned for its engineering expertise-and other technical knowledge institutes. Dutch engineering knowledge has a strong macro-economic component; based on flood probabilities, engineers typically calculate "optimal" protection levels which ensure that the benefits of flood protection outweigh the costs in the long term. Since the 1970s, ecological expertise has been included as an additional source of knowledge in Dutch flood governance. Since this "ecological turn," Dutch flood governance is not only known for its ground- 
breaking engineering technologies, but also for its "polder model" of decision-making in which different (economic, safety, and ecological) stakes have been made part of the process (Disco 2002). Since the 1990s, for example, Rijkswaterstaat has deliberately attempted to also include ecological expertise in its organizational structure (Van den Brink 2009).

Table 1. The policy arrangement underlying the Dutch safety approach.

\begin{tabular}{ll}
\hline \hline $\begin{array}{l}\text { Policy } \\
\text { arrangements } \\
\text { framework } \\
\text { dimension }\end{array}$ & Traditional safety approach \\
\hline Discourse & $\begin{array}{l}\text { Floods are a collective risk, against which protection } \\
\text { should be provided by the central state. } \\
\text { National parliament, Ministry of V\&W, }\end{array}$ \\
Actors & $\begin{array}{l}\text { Rijkswaterstaat } \\
\text { Engineering and macroeconomic expertise, ecological } \\
\text { expertise }\end{array}$ \\
Knowledge & $\begin{array}{l}\text { Optimal flood protection levels } \\
\text { Resources }\end{array}$ \\
$\begin{array}{l}\text { Utilitarian: decision-making power, responsibilities, and } \\
\text { resources are allocated to the central level where } \\
\text { maximized outcomes can be achieved. }\end{array}$ \\
\hline Ministry of Transport, Public Works and Water Management
\end{tabular}

\section{A changing policy discourse: the Room for the River program}

In the 1990s, the Dutch were caught by surprise by a series of (near) flooding incidents. In 1993, the Meuse River burst its banks in the southern province of Limburg, and flooded one-fifth of the provincial surface. This flood put more than 700,000 properties under water, of which many were built in unembanked areas in the river's winter bed. Similar circumstances occurred in 1995. While a large flooding disaster was prevented, anticipation about it led to one of the largest evacuation projects ever undertaken in Dutch history. In the late 1990s and early 2000s, a series of rainfall extremes caused multiple instances of flooding throughout the country, which caused crop and property damage.

The immediate reaction to the 1993 flood event was a typical Dutch one. In parliament, the event was referred to as an "environmental disaster" requiring "national solidarity" (Kamerstukken II 1993/1994a:5). In 1995, a Delta Act Large Rivers was enacted to speed up dike reinforcements in riverine areas. Especially after the 1995 floods, however, this response was also criticized. Partly, these criticisms were instigated by an increased awareness of the impacts of climate change. National and regional water management experts affiliated with Rijkswaterstaat and water boards saw themselves faced with the difficult task of fighting off floods in a more extreme climate for a society that continued to allow developments in flood-prone areas. While throughout history, these engineering experts had always called for building stronger levees to keep the water out, they now started arguing that more space should be reserved for floodwater. This vision was, for example, put forward in an influential report of the Advisory Committee on Water Management in the 21st Century, which was appointed to explore the future challenges for Dutch water management, and whose six-member board included three engineers (Commissie Waterbeheer 21e eeuw 2000).
In Dutch parliament, this view started to prevail as well. Dike reinforcement was criticized for having an "unsustainable character" because it only builds up the value at risk to flooding (Kamerstukken II 1996/1997a:3). Prolongation of this practice was seen as "uneconomical" (Kamerstukken II 1996/1997a:3). Actively supported by Rijkswaterstaat, parliament adopted a new Room for the River Policy Guideline in 1996. With this guideline, the Dutch government sought to increase the discharge capacity of the country's main rivers by giving these rivers more space in the national landscape. To achieve this, the guideline restricted building activities in the rivers' winter beds. New developments were allowed only if they were riverine-tied (e.g., shipping) or represented a major national economic interest, and buildings in the winter bed had to meet with certain safety standards to minimize potential damage (VROM and V\&W 1996).

The Room for the River policy was considered a success. In 2006, the Dutch government incorporated this policy in a Spatial Planning Key Decision, through which it designated and funded a number of river-widening projects in the Netherlands. These developments were supported by new European policies such as the 2000 Water Framework Directive and the 2007 Floods Directive, which required member states to employ more "integrative" approaches to water and flood governance that explicitly take ecological values into account. In the Netherlands, this ecological component was already incorporated by Rijkswaterstaat and the water boards, and ecological improvement hence formed an important additional justification of Room for the River projects.

While river-widening was successful, the planning restrictions imposed by the 1996 policy guideline were experienced as too burdensome, particularly by local communities that wanted to use river beds for economic activities. The 1996 guideline was amended with a new Large Rivers Policy Guideline in 2006, in which the safety requirements for developments in the winter bed were withdrawn (V\&W and VROM 2006). Instead, this 2006 guideline emphasized the individual responsibility of project developers and property owners in the winter bed to take the necessary precautionary measures to deal with the potential impact of a flood (V\&W and VROM 2006:7). Flood insurance was proposed as a means to assist citizens and businesses in acting on this new responsibility (Kamerstukken II 2005/2006a).

In the development of the Room for the River policy, new insights about the impacts of climate change challenged the existing policy discourse on floods. Structural flood defenses were no longer seen to provide an efficient solution in this new context. Rather, spatialplanning measures were needed to ensure safe living conditions in the Dutch delta. While the Room for the River policies implemented in this regard significantly changed the content of flood policies in the Netherlands - they replaced the focus from warding off to accommodating floods - the policies themselves were developed through close collaboration between policymakers and institutionalized engineering experts, whose national cost-benefit analyses were no longer used only to determine optimal flood protection levels but now also to identify economically efficient land use options to create more space for water in the national landscape. Because these cost-benefit analyses remained focused on cost-efficiency in the long term, the organizational structure in Dutch flood governance remained 
largely the same. Floods were still dealt with through top-down (river and landscape) engineering solutions, for which key responsibilities were assigned to the national government, that designated river-widening areas, financed Room for the River projects, and laid down the conditions under which these areas could be used.

Table 2. Changes in the Dutch policy arrangement brought about by the Room for the River program.

\begin{tabular}{ll}
\hline \hline $\begin{array}{l}\text { Policy } \\
\text { arrangements } \\
\text { framework } \\
\text { dimension }\end{array}$ & Room for the River \\
\hline Discourse & $\begin{array}{l}\text { Now that flood risks increase due to climate change, } \\
\text { structural flood defenses no longer provide a complete } \\
\text { solution. }\end{array}$ \\
Actors & $\begin{array}{l}\text { National parliament, Ministry of V\&W, } \\
\text { Rijkswaterstaat } \\
\text { Engineering and macroeconomic expertise, ecological } \\
\text { expertise }\end{array}$ \\
Rules & $\begin{array}{l}\text { Optimal flood protection and land use solutions } \\
\text { Utilitarian: decision-making power, responsibilities, } \\
\text { and resources are allocated to the central level where } \\
\text { maximized outcomes can be achieved. }\end{array}$ \\
\hline${ }^{\dagger}$ Ministry of Transport, Public Works and Water Management
\end{tabular}

\section{New rules: the issue of flood damage compensation}

In contrast to many other (European) countries where some form of flood insurance is available, in the Netherlands, the central government generally covers private losses after a flood event. Up to 1995, governmental damage compensation was offered through different administrative arrangements that targeted different groups. For example, the Ministry of Agriculture arranged damage compensation for farmers, the Ministry of Economic Affairs compensated the damage of private businesses, and individual flood losses were usually reimbursed by the Ministry of Interior. While this was generally accepted as a reasonable and fair way to tailor governmental damage compensation to the specific needs of affected groups (Kamerstukken II 1993/1994b, 1994/1995a), the recurrent character of flooding in the 1990s and 2000s challenged this practice. On the one hand, the arbitrary and ad hoc character of the arrangements was called into question (Kamerstukken II 1995/1996). On the other hand, this practice was seen to assert a moral pressure on the Dutch government to pay out every time a flood struck, an obligation that was no longer deemed tenable now that flood risks had become more structural under climate change, not only because it would become unaffordable, but also because it reduced incentives for taking damage mitigation measures at the local level (Kamerstukken 1994/1995b).

In discussions on damage compensation after the 1993 and 1995 floods, flood insurance has often been proposed as a means to improve existing arrangements for damage compensation in the Netherlands (Kamerstukken II 1994/1995c, d). Flood insurance would not only provide a more orderly method of damage compensation because it operates under fixed rules, it would also incentivize the implementation of loss reduction measures at the local level because these measures would lower the risk and insurance premiums accordingly. The Ministry of Interior and Kingdom Relations, together with the Ministry of V\&W, drafted various proposals to set up an insurance scheme for flood damage in the Netherlands.

However, these proposals always encountered much resistance. In 1995, a draft bill to implement a public-private flood insurance scheme molded after the model used in France, was, for example, sharply criticized by the Council of State for conflicting with the national government's constitutional duty of care for sustaining the quality of the Dutch living environment (Kamerstukken II 1995/1996). Among politicians, the general position also was that flood damage compensation involved questions of national solidarity that should not be left to the market but settled in parliament instead (Kamerstukken II 1995/1996).

In 1998, a new damage compensation act (the "WTS") was adopted as a middle-ground solution. The law intended to balance the goals of legal security, national solidarity, and individual responsibility (Kamerstukken II 1996/1997c). Legal security was provided by specifying the conditions under which the law could be activated, namely, in the case of a large-scale riverine flooding or an event with a similar magnitude. National solidarity was ensured by preserving the responsible minister's freedom to determine the specific compensation rules on a case-by-case basis. Individual responsibility was addressed by arranging for only partial compensation and excluding losses that are reasonably insurable or could be attributed to careless actions.

Applications of this law have been much contested. The law was activated twice in 1998, but when a similar flood event occurred in 1999, it was decided not to activate the law because of the now structural and therefore anticipatory character of flooding in this area (Kamerstukken II 1998/1999a). Moreover, compensation rules were amended for each case, which still resulted in different damage compensation arrangements for different groups (Kamerstukken II 1998/1999b, 2000/2001). Many have claimed the law fails to provide the intended financial security and incentives for damage mitigation (e.g., Faure and Hartlief 2001, Botzen and Van den Bergh 2008). Nevertheless, the government continued to emphasize the responsibility of local actors (communities, citizens) to deal with small-scale flood events; in a number of policy statements and documents, it underscored that the national government has a legitimate role only in cases of large-scale and socially disruptive flooding disasters (CIW 2004:7, Kamerstukken II 2005/2006b:1). The Dutch government also continued to look for opportunities to implement an insurance scheme for flood damage (Kamerstukken II 2005/2006b, 2013/2014). However, while an agrarian rainfall insurance scheme was set up in 2003, attempts to launch a general insurance scheme for flood damage have largely failed up to now (Kok et al. 2014).

The new damage compensation act emphasizes the responsibility of local-level actors to carry their own burden in the event of a flood and take the necessary precautionary measures to mitigate this risk. Strikingly, little new expertise was brought into the policy-making process to support such new responsibility arrangements for flood damage compensation. While the opportunities and drawbacks of implementing a flood insurance scheme in the Netherlands have been analyzed by geography and spatial economy departments of key Dutch knowledge institutions (e.g., Wolsink 2006, Vrijling et al. 2008, Aerts and 
Botzen 2011, Seifert et al. 2013, Kok et al. 2014, de Moel et al. 2014, Paudel et al. 2015), and while this literature underscores the difficulties connected to shifts in responsibility from central-level to local-level actors in the highly centralized and strictly regulated water management and spatial-planning context of the Netherlands, this knowledge has not found its way into the policymaking process. Engineering expertise still formed the dominant source of knowledge in the policy domain, and the focus still was on national-level considerations about efficiency and solidarity. Because of this nationally oriented focus, the practical consequences of shifts in responsibility to the local-level were not always recognized. The question about what individuals could actually do to reduce their exposure to flood risks, for example, was never raised in the policy discussions on flood insurance, which also left aside many questions related to how individuals would do this, whether this is even allowed in the strictly regulated spatial-planning structure of the Netherlands, or who would finance such measures.

Table 3. Changes in the Dutch policy arrangement brought about by discussions on flood insurance and the WTS.

\begin{tabular}{ll}
\hline \hline $\begin{array}{l}\text { Policy } \\
\text { arrangements } \\
\text { framework } \\
\text { dimension }\end{array}$ & Flood insurance/WTS \\
\hline Discourse & $\begin{array}{l}\text { Under climate change, institutionalized damage } \\
\text { compensation practices create adverse incentives for } \\
\text { damage mitigation and offer insufficient financial } \\
\text { security. }\end{array}$ \\
Actors & $\begin{array}{l}\text { National parliament, Ministry of Interior and } \\
\text { Kingdom Relations, Ministry of V\&W }\end{array}$ \\
Knowledge & $\begin{array}{l}\text { Engineering and macroeconomic expertise } \\
\text { Rules to balance legal security, national solidarity, and } \\
\text { individual responsibility. }\end{array}$ \\
Resources & $\begin{array}{l}\text { Partial decentralization of decision-making } \\
\text { competencies and governance responsibilities, but no } \\
\text { decentralization of additional (financial, knowledge) } \\
\text { resources }\end{array}$ \\
\hline \multirow{7}{\dagger}{ Ministry of Transport, Public Works and Water Management }
\end{tabular}

A different allocation of resources? The Second Delta Program In 2007, a Second Delta Committee - the first Delta Committee was formed after a disastrous flood in 1953-was appointed to analyze the state of the flood protection system. Members of this committee included, among others, an economist, a civil engineer, a climate expert, a landscape architect, and the director of a large dredging company. One of main conclusions of this committee was that the Dutch flood defense system not only failed to meet its current standards, but that these standards were too low to adequately prepare the water system for the impacts of climate change in general. The 2008 report of this committee functioned as an alarm bell in Dutch flood governance (Verduin et al. 2012).

With the Second Delta Program, launched in 2008, the Dutch government intends to regenerate Dutch flood protection. The program outlines national water goals and specifies policy strategies. A principle adopted in this program is that of "multilayered safety." Developed by water management professionals, this principle distinguishes between three "safety layers" as the three pillars of Dutch policy-making on floods: a first layer of flood protection, a second layer of climate-proof spatial planning, and a third layer of emergency management (Meijerink and Dicke 2008). Within the Second Delta Program, the Dutch government has formulated so-called "delta decisions" to embody this principle of multilayered safety in practice.

The Delta decision on water safety, which has been put forward as a primary pillar, calls for a revision of Dutch safety standards based on a re-evaluation of the costs and benefits involved with national flood protection (VenW, VROM, LNV 2009). This reevaluation was performed by a group of professionals led by economists at the engineering agency Deltaris. This group developed a new method to calculate what they have termed "economically efficient flood protection standards" for the Netherlands - defined as the point at which further investments in dike reinforcement exceed the gained benefits of mitigated flood damage (Eijgenraam et al. 2014). Justified in reference to their cost-efficiency (Kamerstukken II 2010/2011, 2011/2012, 2013/2014, 2015/2016), this new norm-calculation method was adopted by parliament in 2015 . Using this new method, existing safety norms - which still stem from 1953-will be recalculated and reset, using cost-efficiency as a principle. Thus, standards will be set higher in areas where there are a lot of people or where there is a lot of value to protect, and lower in medium- to lowrisk areas (Delta Program 2015:16). On top of that, the government pronounced that Dutch citizens will be provided with an equal basic safety level, expressed as the annual chance of being killed by a flood of no more than 1:100,000, a standard matched by no other country in the world.

Another Delta decision focuses on spatial adaptation. This decision outlines spatial-planning measures as a means to reduce the impacts of a flood event, and herewith addresses the second and third safety layers. While spatial-planning measures are described as a sensible policy strategy, their importance is specifically highlighted for medium- to low-risk areas where the cost of structural flood protection is unreasonably high compared to the value they protect (Kamerstukken II 2015/2016). Furthermore, the Second Delta Program (2014:8) states that because the spatial-planning sector is locally organized in the Netherlands, spatial-planning measures require "shared ownership" and "self-regulation." By forwarding spatialplanning measures for low- and medium-risk areas, a larger contribution of individuals and businesses in these areas is thus expected.

The choice to protect an area through flood protection or with spatial measures was based on a national cost-benefit analysis, in the case of the Second Delta Program performed by the Deltaris group. Under this national-level focus, the local-level implications of policy choices have not always been clearly recognized in policy discussions. Only in reaction to an assessment of the Organization for Economic Cooperation and Development (OECD 2014), which concluded that Dutch citizens are not well aware of, and are therefore ill-prepared for, the flood risks they face, there has been some discussion about the role of citizens in Dutch flood governance. However, these discussions concentrated on the need to inform citizens about the emergency relief measures they can take during a flood rather than on their role in preventing flood damage through spatial-planning measures (Kamerstukken II 2013/2014, 2015/2016). 
Table 4. Changes in the Dutch policy arrangement brought about by the Second Delta Program.

\begin{tabular}{ll}
\hline \hline $\begin{array}{l}\text { Policy } \\
\text { arrangements } \\
\text { framework } \\
\text { dimension }\end{array}$ & Second Delta Program \\
\hline Discourse & $\begin{array}{l}\text { Climate change requires a reevaluation of Dutch } \\
\text { flood protection. } \\
\text { National parliament, Ministry of I\&M, }\end{array}$ \\
Actors & $\begin{array}{l}\text { Rijkswaterstaat, Deltaris } \\
\text { Engineering and macroeconomic expertise }\end{array}$ \\
$\begin{array}{l}\text { Knowledge } \\
\text { Rules } \\
\text { Resources }\end{array}$ & $\begin{array}{l}\text { Partial decentralization of governance responsibilities } \\
\text { in low- and medium-risk areas, but no } \\
\text { decentralization of additional (financial, knowledge) } \\
\text { resources }\end{array}$ \\
\hline${ }^{\dagger}$ Ministry of Infrastructure and the Environment
\end{tabular}

\section{CONCLUSIONS AND DISCUSSION}

I scrutinized the role of knowledge in the turn from safety to spatial-planning measures in the Netherlands as an example of the wider international trend toward spatially oriented policy approaches in flood governance. I elaborated on the policy arrangements framework with a knowledge dimension that was included as an integral part of the institutional structure in a policy domain to analyze (a) how the policy arrangement - and the knowledge dimension in it - changed during the turn to spatial-planning measures in Dutch flood governance, (b) whether this changed policy arrangement required new forms of knowledge, and (c) to what extent these new forms of knowledge could be organized within the existing institutional structure. This section presents the results of the analysis by answering these three questions, and shortly reflects on the findings from an international perspective.

First, my analysis places the "starting point" of the turn from safety to spatial-planning measures in Dutch flood governance in the 1990s, when institutionalized engineering experts incorporated new insights about the impacts of climate change in their considerations of Dutch water governance. These engineering experts, who under the safety approach were entrusted with the responsibility of protecting the Netherlands against flooding, felt this responsibility was increasingly at jeopardy by the unwarranted development of flood-prone areas and climate change. They started arguing that collective flood defenses no longer provided a sufficient solution to deal with the impacts of climate change because these defense structures allow value to build up in protected areas, which adds to the damage caused by future flooding. A new policy discourse emerged in which floods were understood as risks that are partially produced as a by-product of spatial-planning choices. Under this new policy discourse, new rules were forwarded. Instead of being focused on finding optimal (cost-efficient) safety standards for structural flood protection, engineering and macro-economic expertise was increasingly used to find optimal solutions to adjust the spatialplanning structure in the Netherlands. To implement these solutions, some decision-making and governing responsibilities were decentralized to the local level, where spatial-planning policies are made. The Room for the River and Second Delta Program placed new responsibilities on individuals, businesses, and local communities in outer-dike and low- to medium-risk areas for taking precautionary measures against floods, and the WTS emphasized these local-level responsibilities by linking the availability and level of governmental damage compensation to the structural and anticipatory character of flooding in an area.

This short summary describes the turn to spatial-planning measures in the Netherlands not as a complete shift, but rather as a process of gradual institutional change in which the different dimensions of the PAF changed in response to each other. In this process, a new policy discourse on floods developed in response to new claims about the impacts of climate change by institutionalized engineering experts, new rules were forwarded, and new allocations of responsibilities and costs emerged in the policy domain. However, the actor and knowledge dimensions remained largely the same; policy solutions were still developed in close interaction with Dutch engineering experts, and policy solutions continued to rely on their macro-economic engineering expertise. This accentuates a strong path dependency in sciencepolicy interactions in Dutch flood governance.

Second, the analysis demonstrates that the new policy arrangement in Dutch flood governance placed new knowledge requirements on the policy-making process. Engineering expertise nicely fitted the centralized governance structure that characterized the safety approach in Dutch flood governance. Flood governance strategies were justified in relation to their national cost-benefit balance, and possible negative consequences of policy choices for specific groups were always dealt with through additional ad hoc democratic decision-making. However, because spatial-planning measures decentralized responsibilities in flood governance, they require an up-front evaluation of the impacts of these measures on local-level actors in order to identify potential barriers and needs for local actors to effectively act on their responsibility. For example, what measures are available to local actors to make flood-resilient location choices or to floodproof their buildings, what are the costs involved with taking such measures, and do local actors have sufficient financial resources, knowledge, and decision-making space to actually implement these measures in the Netherlands?

Third, the findings of this analysis indicate that demands for "localized" policy knowledge were difficult to organize in Dutch flood governance. Spatial-planning policies have been developed in close collaboration between policy-makers and institutionalized engineering organizations (Rijkswaterstaat, Deltaris), and have consequently been justified mainly in relation to their national cost-efficiency. While the (im)possibilities and potential impacts of implementing spatial-planning measures in Dutch flood governance have been discussed by geographers and behavioral economists over the last two decades, their knowledge did not find its way into the policy-making process. For an explanation, this analysis points to the strong path dependency of institutionalized science-policy interactions in Dutch flood governance. This path dependency obstructed the incorporation of new types of experts, and thus the organization of new forms of knowledge in the policy-making process underlying the turn to spatial-planning measures in the Netherlands. 
From an international perspective, my findings underscore the importance of diversifying the knowledge base that underlies safety institutions to facilitate the turn to spatial-planning measures in flood governance. Safety approaches typically rely on engineering expertise, whose nationally oriented focus well fits the centralized responsibility structure that characterizes safety institutions. Spatial-planning measures tend to shift governance responsibilities to the local level. In order to find a good balance between national- and local-level responsibilities in new spatial flood governance approaches, new forms of knowledge that provide insight into the local-level policy implications of spatialplanning measures are needed. The Dutch case study findings indicate that it may be difficult to organize these new forms of knowledge due to the strong influence of institutionalized science-policy interactions between engineers and policy-makers that developed under safety approaches to floods. The distinct recognition of a knowledge dimension in the PAF helped to identify and understand this challenge. However, the Netherlands provided an "extreme" case, turning from a strong "flood safety dogma" to spatial-planning measures. In further elaborations, this model could be applied to national contexts where the safety approach has institutionalized to a lesser degree, to analyze whether similar challenges emerge.

Responses to this article can be read online at: http://www.ecologyandsociety.org/issues/responses. php/8952

\section{LITERATURE CITED}

Aerts, J. C. J. H., and W. J. W. Botzen. 2011. Climate change impacts on pricing long-term flood insurance: a comprehensive study for the Netherlands. Global Environmental Change 21 (3):1045-1060. http://dx.doi.org/10.1016/j.gloenvcha.2011.04.005

Arts, B., P. Leroy, and J. van Tatenhove. 2006. Political modernisation and policy arrangements: a framework for understanding environmental policy change. Public Organization Review 6:93-106. http://dx.doi.org/10.1007/s11115-006-0001-4

Arts, B., and J. van Tatenhove. 2004. Policy and power: a conceptual framework between the 'old' and 'new' policy idioms. Policy Sciences 37:339-356. http://dx.doi.org/10.1007/s11077-005-0156-9

Arts, B., J. van Tatenhove, and P. Leroy. 2000. Policy arrangements. Pages 53-69 in J. van Tatenhove, B. Arts, and P. Leroy, editors. Political modernisation and the environment: the renewal of environmental policy arrangements. Kluwer Academic Publishers, Dordrecht/Boston/London. http://dx.doi. org/10.1007/978-94-015-9524-7 4

Bergsma, E., J. Gupta, and P. Jong. 2012. Does individual responsibility increase the adaptive capacity of society? The case of local water management in the Netherlands. Journal of Resources, Conservation and Recycling 64:13-22. http://dx.doi. org/10.1016/j.resconrec.2012.03.006

Birkmann, J., and K. von Teichman. 2010. Integrating disaster risk reduction and climate change adaptation: key challenges- scales, knowledge, and norms. Sustainability Science 5(2):171184. http://dx.doi.org/10.1007/s11625-010-0108-y

Botzen, W. J. W., and J. C. J. M. van den Bergh. 2008. Insurance against climate change and flooding in the Netherlands: present, future, and comparison with other countries. Risk Analysis 28 (2):413-426. http://dx.doi.org/10.1111/j.1539-6924.2008.01035. $\underline{\mathrm{X}}$

Bubeck, P., W. J. W. Botzen, and J. C. J. H. Aerts. 2012. A review of risk perceptions and other factors that influence flood mitigation behavior. Risk Analysis 32(9):1481-1495. http://dx. doi.org/10.1111/j.1539-6924.2011.01783.X

Cash, D. W., W. C. Clark, F. Alcock, N. M. Dickson, N. Eckley, D. H. Guston, J. Jäger, and R. B. Mitchell. 2003. Knowledge systems for sustainable development. Proceedings of the National Academy of Sciences of the United States of America 100 (14):8086-8091. http://dx.doi.org/10.1073/pnas.1231332100

CIW. 2004. Samen leven met grondwater-Visie op het voorkomen en oplossen van stedelijke grondwaterproblemen. [online] URL: http://cawsw.nl/documenten/Zicht $\% 20$ op $\% 20$ grondwater CAW $\%$ 20advies_23082004.pdf

Commissie Waterbeheer 21e eeuw. 2000. Waterbeleid voor de 21e eeuw - Geef water de ruimte en de aandacht die het verdient. [online] URL: http://repository.tudelft.nl/view/hydro/uuid\% 3A102e013a-1357-4087-b9f3-387f877c793f/

Crona, B. I., and J. N. Parker. 2012. Learning in support of governance: theories, methods, and a framework to assess how bridging organizations contribute to adaptive resource governance. Ecology and Society 17(1):32. http://dx.doi. org/10.5751/es-04534-170132

de Moel, H., M. van Vliet, and J. C. J. H. Aerts. 2014. Evaluating the effect of flood damage-reducing measures: a case study of the unembanked area of Rotterdam, the Netherlands. Regional Environmental Change 14(3):895-908. http://dx.doi.org/10.1007/ $\underline{\text { s10113-013-0420-Z }}$

Delta Program. 2014. Synthesedocument Ruimtelijke adaptatie Achtergronddocument B3. [online] URL: http://www.deltacommissaris. n1/deltaprogramma/documenten/publicaties/2014/09/16/

deltaprogramma-2015-achtergronddocument-b3

Delta Program. 2015. Werk aan de Delta. De beslissingen om Nederland veilig en leefbaar te houden. [online] URL: http://www. deltacommissaris.n1/deltaprogramma/documenten/publicaties/2014/09/16/ deltaprogramma-2015

Disco, C. 2002. Remaking "nature" the ecological turn in Dutch water management. Science, Technology \& Human Values 27 (2):206-235. http://dx.doi.org/10.1177/016224390202700202

Eijgenraam, C., J. Kind, C. Bak, R. Brekelmans, D. den Hertog, M. Duits, K. Roos, P. Vermeer, and W. Kuijken. 2014. Economically efficient standards to protect the Netherlands against flooding. Interfaces 44(1):7-21. http://dx.doi.org/10.1287/ inte.2013.0721

Faure, M., and T. Hartlief. 2001. Schade als gevolg van natuurverschijselen: de betekenis van de WTS. Milieu \& Recht 240 246. 
Giddens, A. 1984. The constitution of society. Polity Press, Cambridge.

Hahn, T., P. Olsson, C. Folke, and K. Johansson. 2006. Trustbuilding, knowledge generation and organizational innovations: the role of a bridging organization for adaptive comanagement of a wetland landscape around Kristianstad, Sweden. Human Ecology 34(4):573-592. http://dx.doi.org/10.1007/s10745-006-9035$\underline{\mathrm{Z}}$

Hajer, M. A. 2005. Coalitions, practices, and meaning in environmental politics: from acid rain to BSE. Pages 297-315 in D. R. R. Howarth and J. Torfing, editors. Discourse theory in European politics. Palgrave Macmillan, Basingstoke, UK. http:// dx.doi.org/10.1057/9780230523364_13

Hall, J. W., I. Meadowcroft, P. Sayers, and M. Bramley. 2003. Integrated flood risk management in England and Wales. Natural Hazards Review 4(3):126-135. http://dx.doi.org/10.1061/(asce) $\underline{1527-6988(2003) 4: 3(126)}$

Hartmann, T. 2009. Clumsy floodplains and the law: towards a responsive land policy for extreme floods. Built Environment 35 (4):531-544. http://dx.doi.org/10.2148/benv.35.4.531

Heezik, A. A. S. 2007. Strijd om de rivieren-200 jaar rivierenbeleid in Nederland. Dissertation, Technische Universiteit, Delft, the Netherlands.

Hegger, D. L. T., P. P. J. Driessen, C. Dieperink, M. Wiering, G. T. T. Raadgever, and H. F. M. W. van Rijkswick. 2014. Assessing stability and dynamics in flood risk governance: an emperically grounded research approach. Water Resources Management 28:4127-4142. http://dx.doi.org/10.1007/s11269-014-0732-x

Hegger, D., M. Lamers, A. van Zeijl-Rozema, and C. Dieperink. 2012. Conceptualising joint knowledge production in regional climate change adaptation projects: success conditions and levers for action. Environmental Science \& Policy 18:52-65. http://dx. doi.org/10.1016/j.envsci.2012.01.002

Jasanoff, S., editor 2004. States of knowledge: the co-production of science and social order. Routledge, London, UK.

Johnson, C. L., and S. J. Priest. 2008. Flood risk management in England: a changing landscape of risk responsibility? International Journal of Water Resources Development 24(4):513525. http://dx.doi.org/10.1080/07900620801923146

Jong, P., and M. van den Brink. 2013. Between tradition and innovation: developing Flood Risk Management Plans in the Netherlands. Journal of Flood Risk Management. http://dx.doi. org/10.1111/jfr3.12070

Kamerstukken II. 1993/1994a. 23568, nr. 3. Sdu Uitgevers: The Hague.

Kamerstukken II. 1993/1994b. 23564, nr. 10. Sdu Uitgevers: The Hague.

Kamerstukken II. 1994/1995a. 24071, 5. Sdu Uitgevers: The Hague.

Kamerstukken II. 1994/1995b. 24071, nr. 8. Sdu Uitgevers: The Hague.

Kamerstukken II. 1994/1995c. 24071, 21, herdruk. Sdu Uitgevers: The Hague.
Kamerstukken II. 1994/1995d. 24071, nr. 27. Sdu Uitgevers: The Hague.

Kamerstukken II. 1995/1996. 24640, nr. 1. Sdu Uitgevers: The Hague.

Kamerstukken II. 1996/1997a. 18106, nr. 71. Sdu Uitgevers: The Hague.

Kamerstukken II. 1996/1997c. 25159, nr. 5. Sdu Uitgevers: The Hague.

Kamerstukken II. 1998/1999a. 24071, nr. 36. Sdu Uitgevers: The Hague.

Kamerstukken II. 1998/1999b. 24071, nr. 41. Sdu Uitgevers: The Hague.

Kamerstukken II. 2000/2001. 24071, nr. 56. Sdu Uitgevers: The Hague.

Kamerstukken II. 2005/2006a. 30462, nr. 4. Sdu Uitgevers: The Hague.

Kamerstukken II. 2005/2006b. 29668, nr. 11. Sdu Uitgevers: The Hague.

Kamerstukken II. 2010/2011. 31710, nr. 20. Sdu Uitgevers: The Hague.

Kamerstukken II. 2011/2012. 31710, nr. 26. Sdu Uitgevers: The Hague.

Kamerstukken II. 2013/2014. 27625, nr. 328. Sdu Uitgevers: The Hague.

Kamerstukken II. 2015/2016. 34300-J, nr. 6. Sdu Uitgevers: The Hague.

Kingdon, J. 1995. Agendas, alternatives and public policies. Harper Collins, New York, New York, USA.

Klijn, F., P. Samuels, and A. van Os. 2008. Towards flood risk management in the EU: state of affairs with examples from various European countries. International Journal of River Basin Management 6(4):307-321. http://dx.doi.org/10.1080/15715124.2008.9635358

Kok, M., L. van Vliet, and F. Klijn. 2014. Deltafact-Verzekeren van overstromingsschade. [online] URL: http://deltaproof.stowa. nl/pdf/Verzekeren van overstromingsschade?rId=54

Liefferink, D. 2006. The dynamics of policy arrangements: turning around the tetrahedron. Pages 45-68 in B. Arts and P. Leroy, editors. Institutional dynamics in environmental governance. Springer, Dordrecht, the Netherlands.

Maasen, S., and P. Weingart, editors. 2005. Democratization of expertise? Exploring new forms of scientific advice in political decision-making. Kluwer Academic Publishers, Dordrecht, the Netherlands.

McDonnell, R. A. 2008. Challenges for integrated water resources management: How do we provide the knowledge to support truly integrated thinking? International Journal of Water Resources Development 24(1):131-143. http://dx.doi.org/10.1080/07900620$\underline{701723240}$ 
March, J., and J. Olsen. 1989. Rediscovering institutions. Free Press, New York, New York, USA.

Meijerink, S. 2005. Understanding policy stability and change. The interplay of advocacy coalitions and epistemic communities, windows of opportunity, and Dutch coastal flooding policy 19452003. Journal of European Public Policy 12(6):1060-1077. http:// dx.doi.org/10.1080/13501760500270745

Meijerink, S., and W. Dicke. 2008. Shifts in the public-private divide in flood management. Water Resources Development 24 (4):499-512. http://dx.doi.org/10.1080/07900620801921363

Organisation for Economic Co-operation and Development (OECD). 2014. OECD studies on water: water governance in the Netherlands fit for the future? [online] URL: https://www. rijksoverheid.nl/documenten/rapporten/2014/03/17/oecd-studieson-water-water-governance-in-the-netherlands-fit-for-the-future

Paudel, Y., W. J. W. Botzen, J. C. J. H. Aerts, and T. K. Dijkstra. 2015. Risk allocation in a public-private catastrophe insurance system: an actuarial analysis of deductibles, stop-loss, and premiums. Journal of Flood Risk Management 8(2):116-134. http://dx.doi.org/10.1111/jfr3.12082

Penning-Rowsell, E. C., and J. Pardoe. 2012. Who benefits and who loses from flood risk reduction? Environment and Planning C: Government and Policy 30(3):448-466. http://dx.doi. org/10.1068/c10208

Pottier, N., E. Penning-Rowsell, S. Tunstall, and G. Hulbert. 2005. Land use and flood protection: contrasting approaches and outcomes in France and in England and Wales. Applied Geography (25):1-27. http://dx.doi.org/10.1016/j.apgeog.2004.11.003

Rathwell, K. J., and G. D. Peterson. 2012. Connecting social networks with ecosystem services for watershed governance: a social-ecological network perspective highlights the critical role of bridging organizations. Ecology and Society 17(2):24. http:// dx.doi.org/10.5751/es-04810-170224

Seifert, I., W. J. W. Botzen, H. Kreibich, and J .C. J. H. Aerts. 2013. Influence of flood risk characteristics on flood insurance demand: a comparison between Germany and the Netherlands. Natural Hazards and Earth System Sciences 13:1691-1705. http:// dx.doi.org/10.5194/nhess-13-1691-2013

Van den Brink, M. 2009. Rijkswaterstaat on the horns of a dilemma. Eburon, Delft, the Netherlands.

van der Brugge, R., J. Rotmans, and D. Loorbach. 2005. The transition in Dutch water management. Regional Environmental Change 5:164-176. http://dx.doi.org/10.1007/s10113-004-0086-7

van Herk, S., C. Zevenbergen, R. Ashley, and J. Rijke. 2011. Learning and action alliances for the integration of flood risk management into urban planning: a new framework from empirical evidence from the Netherlands. Environmental Science \& Policy 14(5):543-554. http://dx.doi.org/10.1016/j.envsci.2011.04.006

Van Tatenhove, J., B. Arts, and P. Leroy, editors. 2000. Political modernization and the environment: the renewal of environmental policy arrangements. Kluwer, Dordrecht, the Netherlands.
V\&W and VROM. 2006. Beleidslijn grote rivieren. [online] URL: https://www.rijksoverheid.n1/documenten/kamerstukken/2006/07/26/ beleidslijn-grote-rivieren [4-2-2016].

VenW, VROM, and LNV. 2009. Beleidsnota Waterveiligheid 2009-2015. [online] URL: http://edepot.wur.n1/15819

Verduin, S. H., S. V. Meijerink, and P. Leroy. 2012. How the Second Delta Committee set the agenda for climate adaptation policy: a Dutch case study on framing strategies for policy change. Water Alternatives 5(2):469-484.

Vink, M. J., D. Boezeman, A. Dewulf, and C. J. A. M. Termeer. 2013. Changing climate, changing frames: Dutch water policy frame developments in the context of a rise and fall of attention to climate change. Environmental Science \& Policy 30:90-101. http://dx.doi.org/10.1016/j.envsci.2012.10.010

Vis, M., F. Klijn, K. M. de Bruin, and M. van Buuren. 2003. Resilience strategies for flood risk management in the Netherlands. International Journal of River Basin Management 1 (1):33-40. http://dx.doi.org/10.1080/15715124.2003.9635190

Vrijling, J. K., C. J. J. Eijgenraam, and M. Kok. 2008. Verzekeren tegen grote overstromingen. Expertise Netwerk Waterveiligheid, Utrecht, the Netherlands.

VROM and V\&W. 1996. Beleidslijn ruimte voor de rivier. [online] URL: http://publicaties.minienm.nl/documenten/beleidslijn-ruimtevoor-de-rivier

Ward, P. J., W. P. Pauw, M. W. van Buuren, and M. A. Marfaie. 2013. Governance of flood risk management in a time of climate change: the cases of Jakarta and Rotterdam. Environmental Politics 22(3):518-536. http://dx.doi.org/10.1080/09644016.2012.683155

Wiering, M. A., and B. J. M. Arts. 2006. Discursive shifts in Dutch river management: 'deep' institutional change or adaptation strategy? Hydrobiologia 565(1):327-338. http://dx.doi.org/10.1007/ s10750-005-5923-2

Wiering, M. A., and I. Immink. 2006. When water management meets spatial planning: a policy-arrangements perspective. Environment and Planning C: Government and Policy 24(3):423438. http://dx.doi.org/10.1068/c0417j

Wolsink, M. 2006. River basin approach and integrated water management: governance pitfalls for the Dutch Space-WaterAdjustment Management Principle. Geoforum 37:473-587. http://dx.doi.org/10.1016/j.geoforum.2005.07.001

Yin, R. K. 2009. Doing case study research. Fourth edition. Sage, Thousand Oaks, California, USA. 